\title{
The following are meeting reports received at AMS Headquarters on or before 15 January.
}

\section{Albuquerque}

The program for November featured Duffy Paxton of the National Weather Service office here, who had been stationed on the Queen Elizabeth Islands in the Arctic for a year and had collected many excellent Eskimo artifacts as well as a number of spectacular slides of the Far North.

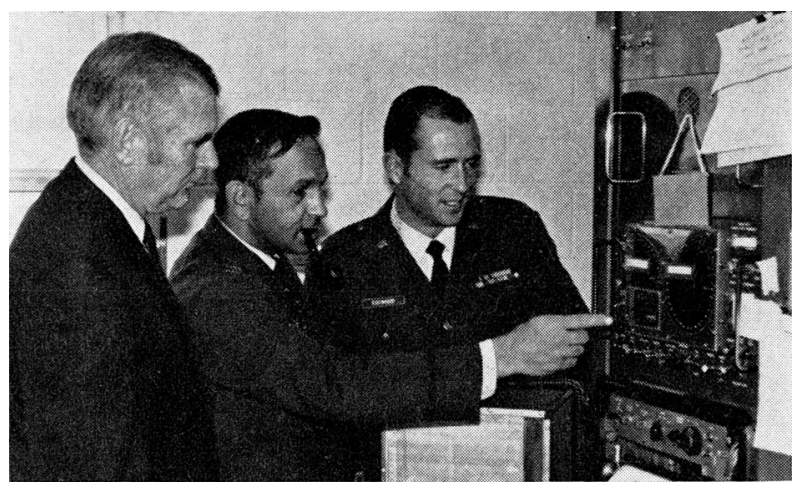

Officers elected at the November meeting are pictured above inspecting the new WBRT-57 system at the NWS Automatic Radiosonde Launching Site. Capt. Ronald J. Nelson (ctr), commander of the AWS Detachment 23, 6th Weather Wing and staff meteorologist for the Air Force Weapons Laboratory at Kirtland AFB, chairman; Frank W. Eldred (1), meteorologist at the Albuquerque office of the National Weather Service, vice chairman; and 1st Lt. William O. Eisenhood (r), assistant staff meteorologist AFWL, secretary-treasurer, discuss the operation of the instrument and its computer tie-in which provides rapid determination of the upper-air data.-William O. Eisenhood, Secy.

\section{Central Indiana}

The fall meeting of the chapter was held on 6 November at Indiana State University, Terre Haute, in conjunction with the annual Indiana Academy of Science meeting.

Following a luncheon, a chapter business meeting was held. Highlighting this session was the awarding of centennial medallions honoring colleagues with over 30 years of service to the meteorological profession: Stanley Rampy, Escal Bennett, Paul Miller, Glen Sachse, Edmund Striker, Raymond Powell, Fred Ackelow, Parley Lucas, B. B. Whittier, Clyde Downes, William Trabits, Fred Maher and Kenneth Hunt.-Phillip J. Smith, Secy.

\section{Central North Carolina}

A network of cooperative observers, mostly Society members, within a $40-\mathrm{km}$ radius of the Raleigh-Durham Airport is being organized by the chapter. The network will be called Triangle Area Critical Warning Observation Network; and, in cooperation with the National Weather Service Forecast Office, the members will aid in severe weather warnings, and analysis of precipitation and temperature. The end result will be a microscale coverage of these weather elements for the Raleigh, Durham, and Chapel Hill area. A volunteer corps of about 40 observers is being utilized. Site surveys and procurement of instrumentation are now in progress.

The chapter will support both the North Carolina State Science Fair at Chapel Hill in April 1971 and the earlier district fair for the Triangle area at Durham.

The November meeting was a talk by Maj. Gary Atkinson of AWS Headquarters, Scott AFB, Ill., who informed us of developments in tropical meteorology.-Thomas G. Weaver, Secy.

\section{City College of New York (Student)}

The present officers of the chapter are Arthur Lindner, president; Jan Finkelstein, vice president; Kenneth Hor, secretary; and Richard Namm, treasurer. Faculty advisors are Michael Tomlinson and Prof. Stan Gedzelman.

The members are enthusiastically participating in the national forecasting contest, and we expect enthusiasm to mount with the installation of a newly acquired circuit " $\mathrm{C}$ " teletype machine.-Kenneth Hor, Secy.

\section{Connecticut Valley}

Kickoff speaker for the regular chapter meetings of this season was William Danielson, staff meteorologist at the Talcott Mountain Science Center and chapter vice president. At the 27 October meeting he gave a short talk on "Weather on the planets," illustrated with direct observations of the planets through the Science Center's telescopes.

Conrad Gosset, general manager of Weather Surveys, Pleasantville, N. Y., explained "The varied aspects of private meteorology" at the 24 November meeting, held in the Aviation Lounge of Bradley International Airport.-M. Roland Laro, Pres.

\section{District of Columbia}

"Private meteorology: Agony and ecstacy" was the topic of Louis Allen, popular weather forecaster for WMAL-TV and president of Allen Weather Corporation. Approximately 130 members and guests were present to hear him at the 18 November meeting.

$\mathrm{Mr}$. Allen began by thanking the many people of the $\mathrm{Na}$ tional Weather Service who help make it possible for him to operate a private weather service. He traced the history of his television career, beginning as an unpaid announcer in 1948 when public television was in its infancy. Pay, the annual renegotiation of the TV contract, and switching from 


\section{THE METEOROLOGICAL RECEIVER}

\section{Metrodata's MR 17 Operates in both meteorological bands with radiosondes,}

Metrodata's Model MR 17 is a portable unit which can be easily used in fixed or mobile installations. Operation is made easy by dual tuners and straightforward controls. Reliable all solid state construction. Two companion modules are the RD 5 data converter for radiosonde signals and the PD 15 demodulator for detecting pulse position modulated signals. All units operate on small amounts of 50-400 $\mathrm{Hz}$ power, allowing use on small boats or aircraft.
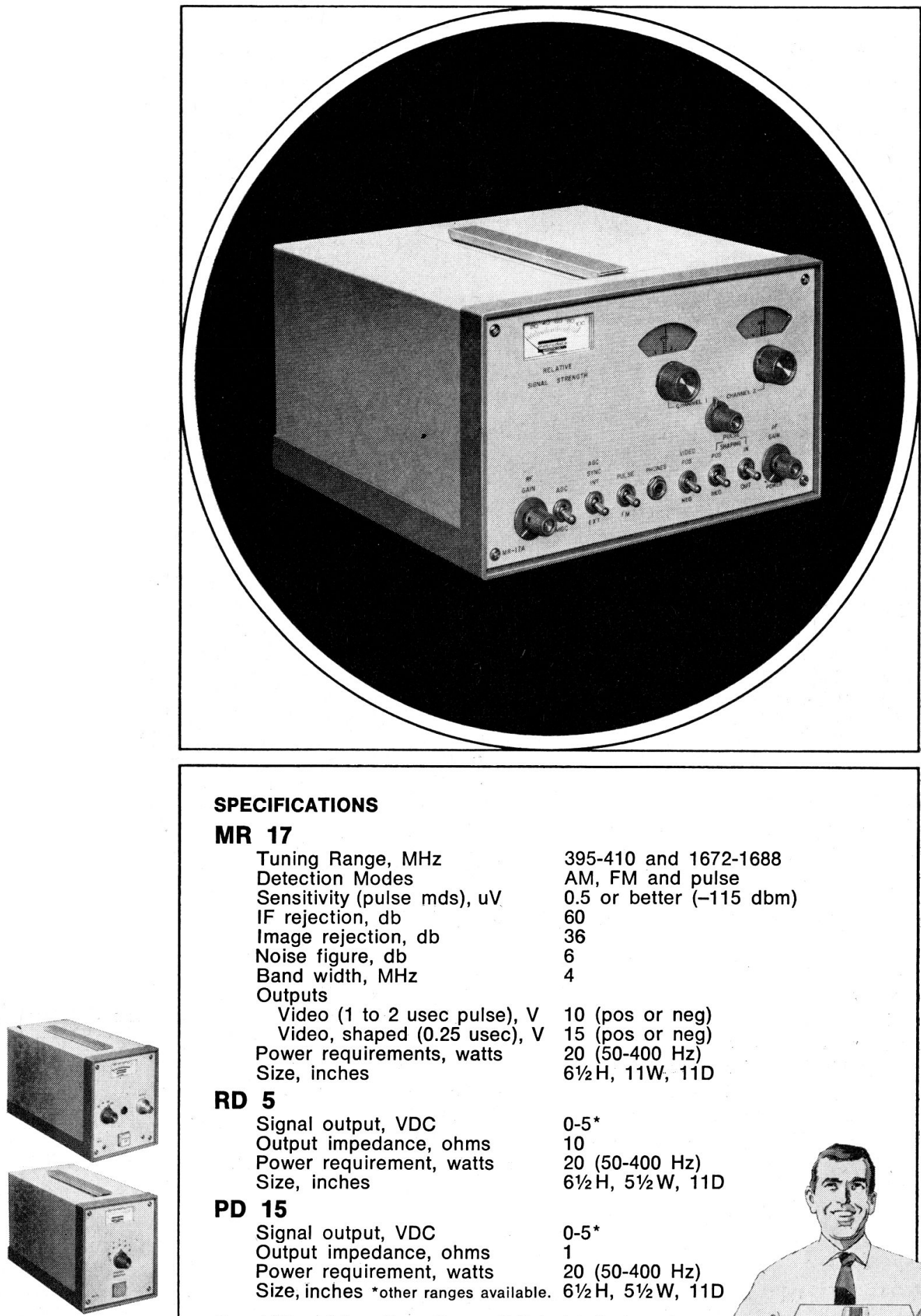

\section{SPECIFICATIONS}

\section{MR 17}

Tuning Range, $\mathrm{MHz}$

Detection Modes

Sensitivity (pulse mds), uV

IF rejection, $d b$

Image rejection, $\mathrm{db}$

Noise figure, $\mathrm{db}$

Band width, $\mathrm{MHz}$

Outputs

Video (1 to 2 usec pulse), V 10 (pos or neg)

Video, shaped (0.25 usec), V 15 (pos or neg)

Power requirements, watts $20(50-400 \mathrm{~Hz})$

Size, inches

RD 5

Signal output, VDC

Output impedance, ohms

Power requirement, watts

Size, inches

$61 / 2 \mathrm{H}, 11 \mathrm{~W}, 11 \mathrm{D}$

PD 15

Signal output, VDC

Output impedance, ohms

Power requirement, watts

For additional information write or call Metrodata Systems, Inc. 
one network to another have been traumatic, but this situation has improved and become more stable.

His company specializes in ship routing. This science is the outgrowth of ideas originated by $\mathrm{Mr}$. Allen while he was employed by the Naval Oceanographic Office many years ago. It has now expanded into an extensive program by our own Navy and by several other countries.

Mr. Allen expressed pride in his profession and in the fact that on television he speaks with the authority of a professional meteorologist. Private meteorology is a difficult field, characterized by psychological pressure on the individual, but "makes life interesting." He hopes to experiment with symbolic logic as a way of marrying the subjective and objective approaches to weather forecasting. In fielding questions, Mr. Allen defended use of his own forecast for the TV program with arguments that subjective skill is still needed in making weather forecasts, and that he must answer directly and personally for the accuracy of his predictions.

A business meeting preceded the main program.-Rolf $M$. Nilsestuen, Recording Secy.

\section{El Paso}

The chapter met in November for dinner and a speech by Capt. Alva L. Wallis, staff meteorologist from Holloman AFB, N. Mex., on "Environmental considerations at the rocket sled track." After describing the 7-mile long track and its uses, Capt. Wallis showed a movie of sled tests on the track narrated by Col. Stapp, a noted expert on deceleration testing.

\section{Greater St. Louis}

The 20 November meeting at the Scott Officers' Club celebrated the centennial of the U. S. Weather Services, the Golden Anniversary of the AMS, and the 33rd birthday of the Air Weather Service, and honored Eugene Bollay, president of the AMS, for outstanding service during his tenure in office. The attendance of 286 members and guests represents a new chapter high.

A cocktail hour and dinner preceded the business meeting. Chairman William Best introduced Mr. Bollay. In his remarks Mr. Bollay reviewed the 100 years of U. S. weather service, noting the contributions of the USAF Air Weather Service, the National Weather Service and the American Meteorological Society in improving environmental services. He noted that synoptic observations by the Army Signal Corps in 1870 were the forerunner of today's weather service, and that this century has seen weather service pass from kites to satellites. Both the AWS and NWS were commended for pioneering efforts to apply weather information to operational problems. He cited the aircraft reconnaissance program, the new efforts in solar forecasting, and severe storm forecasting as examples of AWS contributions. NWS innovations include flood forecasting and weather services for agricultural interests.

Turning to the Society, Mr. Bollay felt that the greatest contributions of the AMS have been in the traditional areas of a scientific society. AMS professional publications and meetings have a world-wide reputation for excellence. He closed by noting that major contributions in advancing the professionalism of meteorology can be made at the grass roots and challenged members with this question: "What are you doing to provide increased professionalism in meteorology?"

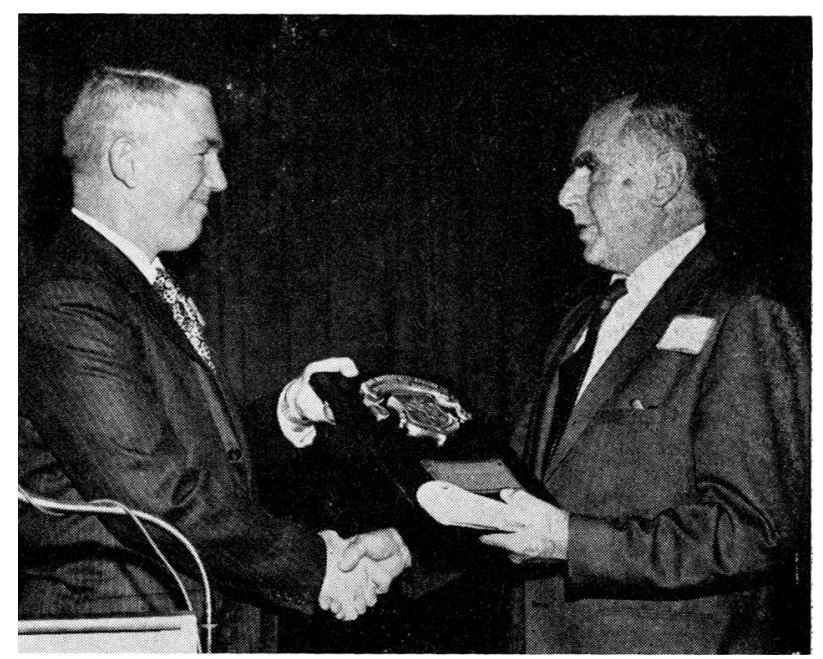

Following the speech, Chairman Best (l) presented Mr. Bollay (r) with a plaque in honor of his outstanding leadership of the Society and his contributions to the meteorological community.

The business meeting then adjourned and was followed by a 30-minute comedy skit on several of the more humorous events in the 100 years of weather services. Music and dancing ended the evening.-Gene J. Pfeffer, Secy.

\section{New York City}

Paul W. Kadlec, manager of meteorology for Continental Airlines, spoke on the airborne detection of clear air turbulence at the 8 December meeting, held at the Eastern Regional Headquarters of the National Weather Service, Garden City. He showed a schematic of the Barnes infrared temperature detector, photographs of its installation in a commercial jet airliner, and a section of the 12 channels of information recorded in an encounter with moderate clear air turbulence. He then presented a tabular summary of 750 turbulence cases with their temperatures and temperature changes. He mentioned that the $18.3-\mathrm{m}$ radar antenna at Wallops Island, Va., is able to detect turbulence below $6 \mathrm{~km}$ with complete accuracy.-Joseph Gardner, Secy.

\section{North Alabama}

David Williams, air pollution control officer for the city of Huntsville, showed a 20-minute introductory film "To Clear the Air" and described pollution and its control in the Huntsville area. The film catalogued various pollutants and control devices, providing an introduction to air pollution terminology and concepts.

Huntsville is the only city in Alabama with an air pollution control officer paid by the city. The local Air Pollution Control Board Office and Advisory Control Board were created in 1964. Mr. Williams stated that the annual average particulate level in the Huntsville air has since decreased by almost $50 \%$ from $120 \mu \mathrm{g} \mathrm{m}^{-3}$ to $64 \mu \mathrm{g} \mathrm{m}^{-3}$. Success of local pollution control efforts may be attributed to the foresight of city officials, early public awareness, and cooperation of industry and commerce. Since air pollution control in Alabama is now a state function, Huntsville is fortunate to have existing ordinances on the book for pollution control.

Questions and discussion were held throughout Mr. Williams' presentation.-Novella S. Billions, Secy. 


\section{North Texas}

The 21 October meeting featured two experts in specialized fields of meteorology. Clyde Conner, meteorologist in charge of the New Orleans National Weather Service Forecast Office, gave a talk on "Hurricanes of the Gulf of Mexico," and James Georg, meteorologist in charge of the Lakeland National Weather Service Office, spoke on "Cold weather and Florida citrus."-Bill Crouch, Secy.

\section{Northern Nevada}

A small turnout greeted the first 1970-1971 meeting in Reno. There was no guest speaker, but members informally discussed plans for the coming year.

Twenty-four members and guests attended the November meeting (held 8 December due to poor weather conditions and the Thanksgiving holiday). The business meeting was shortened in order to have time for the two-part program.

Dr. Joseph Warburton of the University of Nevada, Desert Research Institute, Reno, presented a talk on the Alberta Hail Studies Program, which DRI conducted with the University of Alberta and the University of Wyoming during the summer of 1969. He showed an excellent film, complete with sound, that he and Robert Wademan of Wademan Weather Service, Reno, and WeatherMeasure Corp., Sacramento, had made. The Alberta hail-suppression program is a detailed, cooperative effort to stem some of the $\$ 20$ to $\$ 30$ million annual damage suffered in the Canadian prairies. Alberta averages 12 hail days per month in the warm season, with pea- and grape-size hailstones doing most of the damage to crops.

The second part of the program was conducted by Doug Armstrong, meteorologist at the Reno National Weather Service office. He showed several excellent color slides of noctilucent clouds taken while he was assigned to duty in Alaska and explained the theories about these unusual clouds.John W. James, Secy.

\section{Sacramento}

The 5 November meeting featured Dr. Joseph Knox of the Livermore Radiation Laboratory, substituting for Dr. Todd V. Crawford. Dr. Knox read his colleague's paper on "Diffusion of large clouds over long time periods."

In introducing the paper, Dr. Knox commented that the approach used to a solution of the problem was the classical mathematic-physical one. To predict the trajectory of a pollutant cloud and its diffusion in two dimensions, after instantaneous appearance, right cylindrical coordinates (and "similarity" theory where magnitude of the diffusion coefficient depends on the scale of atmospheric motion) were chosen. With three equations in three unknowns, Dr. Crawford used the "marching problem" technique in numerical analysis as a tool. Slides of the "similarity" theory and the solutions generated using the "marching problem" technique illustrated the methods. Additionally, slides showed energy cascading from longer wave motion to lesser motion in diffusion. Three removal mechanisms-dry, wet, and radioactive decay-were included in the discussion.

To verify the model five case studies were conducted involving about 60 instrumented aircraft and several hundred people, mostly for surface deposition observation. The pre- diction procedures matched the experimental data extremely well, indicating that the interaction of atmospheric circulation with large pollutant clouds and the diffusion of pollutants over continents may be predicted with sufficient accuracy to benefit the population.

After a short business session, James R. Kinosian, supervising engineer of the State of California Air Resources Board, discussed the operations and history of the air monitoring program in California at the December chapter meeting.

While air pollution monitoring had its beginnings in the 1940 's, it wasn't until 1952 that Dr. Arie Haagen-Smit was able to demonstrate the existence of photochemical "smog," the synergistic relationship between chemical effluents and sunlight. Even then, the continuous monitoring of suspended particulate matter was not inaugurated until 1957, and then only in Los Angeles. Not until 1962 did a statewide monitoring of pollutants begin. Today, about six pollutantsorganic gases, oxides of nitrogen, oxidants, carbon monoxide, sulfur dioxide, and suspended particulates-are monitored at 73 stations.

The Air Resources Board is responsible for assessing air quality in the 11 natural air basins of California, providing data for pollution control, identifying long-term trends, providing data on pollutant concentrations and their effects on man and the environment, and establishing a basis for emergency action. Mr. Kinosian noted that problems in the air quality surveillance program stemmed from data not always being comparable because of differences in sites, heights of sampling, and distribution, calibration, and operation of sampling instruments. In addition, even though standards have been adopted for pollutants such as carbon monoxide, lead, sulfur dioxide, ozone, and nitrogen dioxide, trends have been difficult to establish due to insufficient time to assess the available data properly.

The question-and-answer period after the lecture dwelt upon some of the monitoring techniques and types of equipment available. The 17 members present at the meeting also conducted a lively discussion with Mr. Kinosian on the nature and dissemination of emergency announcements requiring action by the local citizenry on a voluntary basis and the degree of response to such requests in times of measured high pollution.-Norman S. Benes, Secy.

\section{Southern Nevada}

The fall quarterly meeting of the chapter was held at the U. S. Public Health Service Southwest Radiological Health Laboratory on 26 October. Chairman Donald Henderson opened the meeting and announced that the newly elected vice chairman, Barry ZeVan, had transferred to Minneapolis, Minn., and that the executive committee had selected Virgil E. Quinn to fill the position.

Dr. Patrick Squires, head of the Laboratory of Atmospheric Physics, Desert Research Institute, Reno, presented a talk on the inception and growth of the Desert Research Institute. Especially interesting was the work being conducted in the local area relating to water and air pollution. Laboratory research programs which are being conducted by various inyestigators were discussed along with some recent experimental work on weather modification. -Michael O. Little, Secy. 